\title{
Wanprestasi dalam Pelaksanaan Perjanjian Pinjam Meminjam Pada Lembaga Keuangan Mikro Syariah Karawang
}

\author{
Aam Hernita Sriwulan ${ }^{*}$, Puti Priyana ${ }^{2}$ \\ ${ }^{1,2}$ Fakultas Hukum, Universitas Singaperbangsa Karawang, Indonesia. \\ J1. H.S. Ronggowaluyo, Teluk Jambe, Karawang, Jawa Barat, 41361, Indonesia \\ *Correspondence email: aamhernita14@gmail.com ${ }^{1 *}$, puti.priyana@ fh.unsika.ac.id ${ }^{2}$
}

\begin{abstract}
Abstrak. Pelaksanaan pinjam meminjam uang di Lembaga Keuangan Mikro Syariah (LKMS) Karawang berdasarkan kesepakatan antara kedua belah pihak dengan tujuan memberikan modal untuk pengembangan usaha. Akan tetapi dalam pelaksanaan pemberian pinjaman tersebut masih ditemui permasalahan-permasalahan berupa ingkar janji atau wanprestasi yang dilakukan oleh pihak nasabah debitur. Tujuan dari penelitian ini adalah untuk mengetahui bagaimana pelaksanaan perjanjian pinjam meminjam uang pada Lembaga Keuangan Mikro Syariah (LKMS) X di Karawang, bagaimana bentuk dan faktor penyebab terjadinya wanprestasi pada Lembaga Keuangan Mikro Syariah (LKMS) X di Karawang, serta bagaimana upaya penyelesaian wanprestasi yang dilakukan oleh pihak Lembaga Keuangan (LKMS) X di Karawang. Penelitian ini menggunakan metode yuridis normatif. Berdasarkan hasil penelitian pelaksanaan perjanjian pinjam meminjam pada Lembaga Keuangan Mikro Syariah (LKMS) X di Karawang terikat dengan perjanjian tertulis, bentuk wanprestasi yang terjadi berupa tidak melaksanakan prestasi, melaksanakan prestasi tapi sebagian,melaksanakan prestasi tetapi terlambat. Faktor terjadinya wanprestasi, ketidaktegasan dalam pengambilan keputusan, kurangnya koordinasi, penyalahgunaan dana pinjaman, dan bisnis tidak berjalan lancar. Upaya penyelesaiannya adalah penagihan intensif, penerbitan surat peringatan, panggilan nasabah, perpanjangan jangka waktu pinjaman dan sita jaminan.
\end{abstract}

Kata Kunci: Lembaga Keuangan Mikro Syariah; Perjanjian Pinjam Meminjam; Wanprestasi

\begin{abstract}
The implementation of lending and borrowing money at the Karawang Islamic Microfinance Institution (LKMS) is based on an agreement between the two parties with the aim of providing capital for business development. However, in the implementation of these loans, problems are still encountered in the form of broken promises or defaults made by the debtor customer. The purpose of this research is to find out how the implementation of the loan and loan agreement at the Islamic Microfinance Institution (LKMS) X in Karawang, what are the forms and factors that cause defaults to occur at the X Sharia Microfinance Institution (LKMS) in Karawang, and how the efforts to resolve default carried out by the X Financial Institution (LKMS) in Karawang. This study uses a normative juridical method. Based on the results of research on the implementation of the lending and borrowing agreement at the Sharia Microfinance Institution (LKMS) X in Karawang, it is bound by a written agreement, the form of default that occurs is in the form of not performing achievements, performing achievements but partly, implementing achievements but too late. Factors occur in default, uncertainty in decision making, lack of coordination, misuse of loan funds, and business not running smoothly. Efforts to solve it include intensive collection, issuance of warning letters, customer summons, extension of loan terms and collateral seizure.
\end{abstract}

Keywords: Sharia Microfinance Institutions; Lending and Borrowing Agreements; Default

\section{PENDAHULUAN}

Seiring dengan berkembangnya pertumbuhan perekonomian suatu negara membuat kebutuhan ekonomi masyarakatnya pun ikut berkembang, perkembangan yang paling spesifik yaitu disektor keuangan yang sangat membutuhkan dukungan dari lembaga-lembaga keuangan. Lembaga keuangan merupakan suatu lembaga yang sangat penting dan berpengaruh dalam menjalankan perekonomian suatu negara.

Karena mayoritas masyarakat di Indonesia beragama islam, maka dari itu hadirlah Lembaga Keuangan Mikro Syariah (LKMS) ditengah kehidupan masyarakat. Lembaga Keuangan Mikro Syariah (LKMS) adalah merupakan suatu lembaga keuangan berbadan hukum dengan sistem pelaksanaan operasional usahanya yaitu untuk memberikan pelayanan jasa keuangan berbasis prinsip syariah. Kegiatan yang dilakukan Lembaga Keuangan Mikro Syariah (LKMS) berfokus pada bentuk pembiayaan bukan dalam bentuk simpanan. Pembiayaan disini berdasarkan Pasal 1 ayat (3) Undang-undang Lembaga Keuangan Mikro (UU-LKM) dapat diartikan sebagai :

"Pembiayaan adalah penyediaan dana oleh Lembaga Keuangan Mikro (LKM) kepada masyarakat yang harus dikembalikan sesuai dengan apa yang telah diperjanjikan."

Dalam menjalankan kegiatan usahanya, Lembaga Keuangan Mikro Syariah (LKMS) harus berdasarkan pada ketetuan dan fatwa yang telah ditetapkan dan dikeluarkan oleh Majelis Ulama Indonesia (MUI). Serta diwajibkan

${ }^{1}$ Penjelasan Pasal 1 ayat (3) Undang-undang Lembaga Keuangan Mikro (UU-LKM) 
membentuk Dewan Pengawas Syariah atau disebut DPS yang bertugas untuk mengawasi, memberikan nasihat dan saran kepada direksi dan/atau pengurus Lembaga Keuangan Mikro sesuai dengan ketentuan dan prinsip-prinsip syariah. Lembaga Keuangan Mikro Syariah (LKMS) menjalankan kegiatannya harus berada dalam satu wilayah Desa/Kelurahan, Kecamatan atau Kabupaten/Kota. Apabila Lembaga Keuangan Mikro Syariah (LKMS) melakukan kegiatan usahanya lebih dari satu wilayah Kabupaten/kota, maka Lembaga Keuangan Mikro Syariah (LKMS) tersebut diwajibkan merubah kegiatan usahanya menjadi bentuk Bank.

Lembaga Keuangan Mikro Syariah (LKMS) terdiri dari beberapa bentuk lembaga yang diantaranya ialah Bank Perkreditan Rakyat Syariah (BPRS), Baitul Mal Wat Tanmil (BMT), Koperasi Syariah dan lembaga keuangan syariah lainnya yang telah diatur dan ditentukan dalam Peraturan Otoritas Jasa Keuangan (OJK) Nomor 12/POJK.05/2014 tentang Perizinan Usaha dan Kelembagaan Lembaga Keuangan Mikro (LKM). ${ }^{2}$

Lembaga Keuangan Mikro Syariah (LKMS) saat ini telah banyak hadir di Daerah Karawang dengan berbagai bentuk lembaga, yang bertujuan untuk membantu dan memberikan pinjaman bagi masyarakat yang membutuhkan dana. Adapun para peminjam yang selanjutnya disebut nasabah debitur yang mengajukan pinjaman pada Lembaga Keuangan Mikro Syariah Karawang ini berasal dari masyarakat ekonomi kelas menengah kebawah dan sebagian kecil dari Pegawai Negeri Sipil.

Pelaksanaan pemberian pinjam meminjam yang dilakukan oleh pihak Lembaga Keuangan Mikro Syariah (LKMS) dan pihak peminjam atau nasabah debitur itu berdasarkan atas suatu perjanjian tertulis. Akan tetapi pada kenyataannya masih banyak ditemukan suatu permasalahan dalam pelaksanaan tersebut, diantaranya adalah adanya suatu perbuatan ingkar janji atau yang bisa kita sebut sebagai wanprestasi yang dilakukan oleh pihak nasabah debitur.

Berdasarkan uraian diatas, maka masalah hukum utama yang akan dianalisis dalam penelitian ini yaitu bagaimana pelaksanaan perjanjian pinjam meminjam uang pada Lembaga Keuangan Mikro Syariah (LKMS) X di Karawang?, bagaimana bentuk dan faktor penyebab terjadinya wanprestasi pada Lembaga Keuangan Mikro Syariah (LKMS) X di Karawang?, serta bagaimana upaya penyelesaian wanprestasi yang dilakukan oleh pihak Lembaga Keuangan (LKMS) X di Karawang?.

\section{METODE}

\section{Pendekatan dan Spesifikasi Penelitian}

Dalam penelitian ini penulis menggunakan metode pendekatan yuridis normatif, karena bahan pustaka yang digunakan sebagai bahan utama dalam penelitian ini merupakan bahan hukum primer yang terdiri dari norma dasar atau kaidah, ketentuan atau peraturan dasar, serta peraturan perundang-undangan yang sudah ada. ${ }^{3}$

Spesifikasi penelitian yang dipergunakan adalah deskriptif analisis, yaitu bentuk analisis data penelitian untuk menguji generalisasi hasil penelitian berdasarkan satu sampel. ${ }^{4}$ Analisis tersebut dilakukan pada data primer dan data sekunder yang berkaitan dengan Wanprestasi Dalam Pelaksanaan Perjanjian Pinjam Meminjam Pada Lembaga Keuangan Mikro Syariah Karawang.

\section{Sumber Data dan Teknik Pengumpulan Data}

Sumber data dalam penelitian ini menggunakan data primer dan data sekunder. Teknik pengumpulan data yang digunakan adalah metode penelitian lapangan dengan mewawancarai informan sekaligus narasumber yang telah ditentukan sebelumnya untuk mendapatkan informasi dan data terkait permasalahan yang akan dibahas. Serta penelitian kepustakaan yang dapat dilakukan dengan cara meneliti bahan-bahan pustaka atau yang bisa disebut dengan data sekunder.

\section{Analisis Data}

Dalam penelitian ini data hasil penelitian yang telah terkumpul dan dianalisis secara deskriptif kualitatif, yaitu seluruh data baik primer dan data sekunder diklasifikasikan atau dikelompokkan sesuai dengan permasalahan kemudian dianalisis dan disajikan kedalam bentuk kata verbal bukan dalam bentuk angka.

\section{Lokasi Penelitian}

Penelitian ini dilaksanakan di wilayah hukum Karawang, karena merupakan lokasi Lembaga Keuangan Mikro Syariah X (LKMS) Karawang beroperasi.

\section{HASIL DAN PEMBAHASAN}

\footnotetext{
${ }^{2}$ Peraturan Otoritas Jasa Keuangan

${ }^{3}$ Soerdjono Soekanto dan Sri Mamudji, Penelitian Hukum Normatif suatu tinjauan singkat, (Jakarta:Grafindo Persada, 1994), hlm. 13.
}

${ }^{4}$ Syofian Siregar, Metode Penelitian Kuantitatif, (Jakarta:Kencana, 2017), hlm. 126. 


\section{Pelaksanaan perjanjian Pinjam Meminjam pada Lembaga Keuangan Mikro Syariah (LKMS) X di Karawang}

Pelaksanaan pinjam meminjam uang di Lembaga Keuangan Mikro Syariah (LKMS) Karawang didasarkan pada perjanjian tertulis yang mengikat kedua belah pihak dimana surat perjanjian ini diterbitkan oleh Lembaga Keuangan Mikro Syariah (LKMS) Karawang. Perjanjian pinjam meminjam diatur di dalam Pasal 1754 KUH Perdata, yang berbunyi :

"Suatu perjanjian dengan mana pihak yang satu berjanji akan memberi kepada pihak yang lain suatu jumlah tertentu barang-barang yang menghabiskan karena pemakaian dengan syarat bahwa pihak yang terakhir ini akan mengembalikan sejumlah yang sama dari jenis dan mutu yang sama pula". ${ }^{5}$

Tata cara pelaksanaan melakukan perjanjian pinjam meminjam adalah sebagai berikut :

1. Peminjam mengajukan permohonan kepada pihak Lembaga Keuangan Mikro syariah (LKMS) Karawang.

2. Pihak Lembaga Keuangan Mikro syariah Karawang (LKMS) akan memeriksa kelengkapan syarat syarat berkas yang telah ditentukan.

3. Pihak Lembaga Keuangan Mikro Syariah (LKMS) Karawang melakukan survey usaha ke Lokasi usaha peminjam.

4. Pihak Lembaga Keuangan Mikro Syariah (LKMS) Karawang membuat analisa keuangan terhadap usaha peminjam.

5. Setelah membuat analisa keuangan terhadap usaha si peminjam, dilanjutkan dengan pengajuan terhadap Komite Lembaga Keuangan Mikro syariah Karawang.

6. Melalui pertimbangan setelah peninjauan usaha pinjaman akan disetujui dan kemudian dicairkan kepada pihak peminjam.

\section{Bentuk dan Faktor Wanprestasi pada Lembaga Keuangan Mikro Syariah (LKMS) X di Karawang}

Pengertian mengenai wanprestasi atau ingkar janji dapat kita lihat pada ketentuan Pasal 1243 Kitab UndangUndang Hukum Perdata (KUHPer) yang berbunyi :

"Penggantian biaya, kerugian dan bunga karena tidak dipenuhinya suatu perikatan/perjanjian mulai diwajibkan, bila debitur walaupun telah dinyatakan lalai, tetapi lalai untuk memenuhi perikatan itu, atau jika sesuatu yang harus diberikan atau tidak dilakukannya hanya dapat diberikan atau dilakukan dalam waktu yang melampaui waktu yang telah ditentukan."

Menurut Ahmad Miru, wanprestasi atau ingkar janji dapat berupa perbuatan-perbuatan yang antara lain :

1. Sama sekali tidak memenuhi prestasi;

2. Prestasi yang dilakukan tidak sempurna;

3. Terlambat memenuhi prestasi;

4. Melakukan apa yang dalam perjanjian dilarang untuk dilakukan. ${ }^{6}$

Adapun bentuk wanprestasi yang dilakukan dalam perjanjian pinjam meminjam pada Lembaga keuangan mikro syariah Karawang diantaranya :

1. Tidak melaksanakan prestasi sama sekali

Bentuknya adalah tidak melakukan apa yang telah disanggupi dalam perjanjian yang telah disepakati. pihak peminjam telah lalai dalam melaksanakan perjanjian sebagaimana yang telah disepakati dengan pihak lembaga keuangan syariah cabang Karawang dengan tidak melunasi pinjaman selama 3 (tiga) kali berturut-turut berikut dengan margin keuntungan yang harus dibayarkan.

Dalam pelaksanaannya, bentuk peringatan diberikan oleh Lembaga Keuangan Syariah berupa 3 kali peringatan berupa pemberian surat peringatan. Jika dalam jangka waktu 1 (satu) bulan Nasabah Debitur tidak memenuhi prestasinya maka pihak Lembaga Keuangan akan memberikan surat teguran pertama, selanjutnya jika dalam pemberian surat pertama nasabah debitur tidak memiliki iktikad baik untuk melaksanakan prestasinya sebagaimana yang tercantum dalam surat peringata pertama, maka 3 (tiga) bulan setelah itu pihak lembaga keuangan akan mengirimkan surat peringatan kedua. Terakhir, jika berselang dari 6 (enam) bulan nasabah debitur juga tidak melaksanakan prestasinya terhadap Lembaga Keuangan Syariah, maka pihak lembaga keuangan syariah mengeluarkan surat peringatan ketiga,dan atas peringatan ketiga ini jika nasabah debitur tidak memiliki iktikad baik terhadap lembaga keuangan syariah, maka nasabah debitur dinyatakan wanprestasi.

2. Melaksanakan prestasi tetapi sebagian.

\footnotetext{
${ }^{5}$ Penjelasan Pasal 1754 Kitab Undang-Undang Hukum Perdata

${ }^{6}$ Ahmadi Miru, Hukum Kontrak dan Perancangan Kontrak, Rajawali Pers, Jakarta: 2007, hlm. 74
} 
Bentuknya adalah melakukan apa yang diperjanjikan akan tetapi hanya sebagian. peminjam atau nasabah debitur tidak melunasi angsuran pinjaman sesuai dengan jangka waktu yang telah ditetapkan dalam perjanjian. Si peminjam hanya membayar bunga pokok dari total pembiayaan yang disalurkan, padahal dalam perjanjian ditetapkan bahwa si peminjam harus membayar angsuran sesuai dengan jangka waktu yang telah ditetapkan berikut dengan margin keuntungannya.

3. Melaksanakan prestasi akan tetapi terlambat.

Bentuknya adalah peminjam tidak melaksanakan prestasi sebagaimana yang diatur dalam surat perjanjian yang mengikat para pihak. ketika sudah tidak memenuhi prestasi pihak Lembaga Keuangan Mikro Syariah (LKMS) Karawang akan mengeluarkan surat peringatan satu, dua dan tiga serta melakukan pemanggilan nasabah untuk segera melunasi pinjaman uang yang telah diberikan sebagaimana yang ditentukan dan disepakati di dalam perjanjian. kadangkala si peminjam baru membayar angsuran pinjaman setelah dilakukan pemanggilan oleh pihak lembaga keuangan syariah Mikro Karawang. ${ }^{7}$

Menurut Abdul kadir Muhammad, terjadinya suatu wanprestasi atau ingkar janji dapat disebabkan oleh adanya 2 (dua) kemungkinan yaitu:

1. Keadaan memaksa (overmacht/force mejeur).

2. Karena kesalahan debitur, baik karena kesengajaan maupun lalai. ${ }^{8}$

Adapun yang menjadi faktor terjadinya wanprestasi dalam pelaksanaan perjanjian pinjam meminjam uang di Lembaga Keuangan Mikro syariah Karawang diantaranya adalah sebagai berikut :

1. Ketidaktegasan dalam pengambilan keputusan saat pemberian pinjaman.

Maksudnya disini adalah ketika nasabah debitur ingin mengajukan pinjaman dan telah memenuhi syarat serta prosedur yang ada, kadangkala komite mempertimbangkan pemberian pinjaman adalah digunakan sebesarbesarnya dengan tujuan dan pemikiran untuk kesejahteraan masyarakat. Karena hal tersebut itulah sangat jarang ketika nasabah debitur telah memenuhi syarat dan prosedur yang ada, permohonan pengajuan pinjaman ditolak oleh komite.

2. Kurangnya koordinasi yang terjalin antara pihak kantor dan pihak survey usaha.

Maksudnya disini adalah koordinasi yang terjadi kadangkala sangat rendah antara satu pegawai dan pegawai lainnya dalam hal pencapaian tujuan sebagaimana yang telah ditetapkan. Kurangnya koordinasi ini menyebabkan kurangnya komunikasi yang baik sehingga hasil yang dicapai tidak maksimal.

3. Penyalahgunaan dana pinjaman oleh si peminjam/nasabah debitur.

Dalam hal pemberian pinjaman dimana pinjaman yang ditujukan adalah pinjaman yang diberikan dengan tujuan pengembangan usaha kadangkala tidak dilaksanakan sepenuhnya oleh nasabah debitur. Uang pinjaman yang diberikan justru digunakan untuk membeli barang barang pribadi dan habis untuk kebutuhan sehari hari karna pemasukan dan pengeluaran yang tidak seimbang oleh nasabah debitur. Karena hal inilah yang membuat nasabah debitur sulit untuk melunasi angsuran pinjaman yang akan dbayarkan kepada pihak Lembaga Keuangan Mikro Syariah (LKMS) Karawang.

4. Usaha peminjam tidak berjalan dengan lancar.

Kadangkala nasabah debitur dalam mengembangkan serta menjalankan usahanya menghadapi berbagai kendala diluar kendali nasabah debitur. Sehingga hal ini menyebabkan nasabah debitur tidak mampu melunasi pinjamannya terhadap Lembaga Keuangan Mikro Syariah (LKMS) Karawang. Kendala-kendala yang dihadapi mulai dari faktor persaingan usaha dilingkungan yang sangat ketat,faktor kebijakan publik yang dibuat oleh pemerintah setempat misalnya terhadap pandemik covid 19 yang sedang dihadapi saat ini, pemerintah menghimbau untuk menghindari keramaian. ${ }^{9}$

\section{Upaya penyelesaian wanprestasi yang dilakukan oleh Lembaga Keuangan Mikro Syariah (LKMS) X Karawang}

Adapun untuk upaya penyelesaian wanprestasi atau ingkar janji yang terjadi pada Lembaga Keuangan Mikro Syariah (LKMS) X yang ada di Karawang yaitu :

1. Penagihan secara Intensif setiap bulan.

${ }^{7}$ H. Sukamdi, Wawancara, Manajer Lembaga Keuangan Mikro Syariah X di Karawang, pada tanggal 5 Januari 2021, pukul 13.20 WIB

${ }^{8}$ Abdulkadir Muhammad dan Rilda Murniati, Segi Hukum Lembaga Keuangan Dan Pembiayaan, (Bandung Citra Aditya Bakti,2000), hlm.250.

${ }^{9}$ H. Sukamdi, Wawancara, Manajer Lembaga Keuangan Mikro Syariah X di Karawang, pada tanggal 5 Januari 2021, pukul 13.20 WIB 
Cara ini dilakukan dengan cara memeriksa pembukuan dan laporan hasil pembayaran para peminjam tiap bulannya. apabila ada peminjam yang telah menunggak selama 1 ( satu ) bulan maka petugas akan menelfon peminjam dengan cara mengingatkan pembayaran angsuran pinjaman.

2. Pemberian surat peringatan

a. Surat Peringatan Satu

Cara ini dilakukan apabila nasabah debitur telah terbukti tidak melunasi angsuran pinjamannya selama 2 ( dua ) bulan berturut turut, surat ini diberikan sebagai peringatan pertama agar si peminjam segera melunasi pinjamannya.

b. Surat Peringatan Dua

Cara ini dilakukan apabila nasabah debitur terbukti telah tidak melunasi angsuran pinjamannya selama 3 ( tiga ) bulan berturut tutut, surat ini diberikan sebagai peringatan kedua agar di peminjam segera melunasi pinjamanya.

c. Surat Peringatan Tiga

Cara ini dilakukan apabila nasabah debitur terbukti telah tidak melunasi pinjamannya selama 6 ( enam)

bulan berturut turut. surat ini merupakan surat peringatan terakhir agar si peminjam segera melunasi pinjamannya.

3. Pemanggilan nasabah peminjam yang wanprestasi guna musyawarah.

Pada tahap ini pihak Lembaga Keuangan Mikro Syariah (LKMS) X di Karawang akan menanyakan kepada nasabah debitur mengapa ia tidak mampu melunasi pinjamannya dan menawarkan untuk mencari solusi terbaik guna mempermudah kedua belah pihak.

4. Perpanjangan jangka waktu angsuran pinjaman.

Setelah dilakukan musyawarah mufakat sehingga akan terdapat solusi dan persetujuan antara kedua belah pihak, jika memang memungkinkan akan dilakukan perpanjangan masa angsuran pinjaman, hal ini dilakukan mengingat tujuan dari Lembaga Keuangan Mikro Syariah (LKMS) X di Karawang adalah untuk kesejahteraan masyarakat. Maka dari itu, salah satu cara yang ditempuh dalam hal mencapai tujuan kekeluargaan dalam sengketa yang terjadi dilakukanlah perpanjangan jangka waktu angsuran pinjaman.

5. Sita jaminan

Apabila dalam proses musyawarah mufakat tidak menemukan solusi dan persetujuan antara kedua belah pihak, maka pihak Lembaga Keuangan Mikro Syariah (LKMS) X di Karawang akan melakukan sita jaminan pada jaminan yang dijaminkan oleh pihak nasabah debitur ketika meminjam uang.

\section{SIMPULAN}

Berdasarkan uraian hasil penelitian diatas, maka penulis dapat memberikan kesimpulan diantaranya :

1. Pelaksanaan perjanjian pinjam meminjam di Lembaga Keuangan Mikro Syariah (LKMS) X di Karawang berdasarkan pada kesepakatan bersama dimana dalam perjanjian tersebut berisi hak dan kewajiban yang harus dipatuhi oleh kedua belah pihak.

2. Bentuk dan faktor penyebab terjadinya wanprestasi dalam pelaksanaan perjanjian pinjam meminjam pada Lembaga Keuangan Mikro (LKMS) X di Karawang diantaranya adalah ketidaktegasan dalam pengambilan keputusan saat hendak memberikan pinjaman, kurangnya koordinasi antara pihak kantor dan pihak survey usaha, penyalahgunaan dana pinjaman oleh peminjam, dan usaha peminjam tidak berjalan dengan lancar.

3. Adapun upaya penyelesaian wanprestasi yang dilakukan pada Lembaga Keuangan Mikro (LKMS) X di Karawang diantaranya penagihan secara intensif setiap bulan, pemberian surat peringatan, pemanggilan nasabah peminjam yang wanprestasi guna musyawarah, perpanjangan jangka waktu kredit dan sita jaminan.

\section{DAFTAR PUSTAKA}

\section{Buku}

Abdulkadir Muhammad dan Rilda Murniati, Segi Hukum Lembaga Keuangan Dan Pembiayaan, Bandung Citra Aditya Bakti,2000.

Ahmad Miru, Hukum Kontrak dan Perancangan Kontrak, Jakarta:Rajawali Press,2007.

Soerdjono Soekanto dan Sri Mamudji, Penelitian Hukum Normatif suatu tinjauan singkat, Jakarta:Grafindo Persada, 1994.

Syofian Siregar, Metode Penelitian Kuantitatif, Jakarta,Kencana 2017.

\section{Peraturan Perundang-Undangan}

Undang-undang Lembaga Keuangan Mikro

Peraturan Otoritas Jasa Keuangan

Kitab Undang-Undang Hukum Perdata 